\title{
Сравнительно-правовой анализ режима трансграничных минеральных ресурсов по международному праву \\ и по национальному законодательству
}

\section{Зикиряходжсаев Л.Д.*}

Проблема рационального использования недр остро актуальна. Многие страны вовлечены в сотрудничество в сфере недропользования. Проводятся международные конференции, заключаются межгосударственные соглашения, вносятся изменения и дополнения в национальные законодательства. Как отмечено в литературе, нефть, газ, уголь, руды и иные минеральные ресурсы нашей планеты - величайшее сокровище, их разведанные запасы иссякают с каждым годом, а перспективы обнаружения новых и практического вовлечения в экономический оборот достаточно неопределенны. Не случайно, что теория неотвратимости «природного голода» находит все больше сторонников в экономической науке: современная добыча невозобновимых природных ресурсов, по мнению авторитетных экономистов, сокрашает их количество, которое потенциально может быть использовано в будущем. Это породило страх, что все страны мира исчерпают все указанные ресурсы и их исчезновение поставит предел экономическому росту'.

Многие государства заняты поиском совершенствования своего законодательства в сфере недропользования, в том числе те, которые недавно сформировались как независимые государства и право которых только формируется. При этом в качестве ориентира для законотворчества в этой специальной области избрано международное право.

В этой связи в настоящей статье исследуются законы о минеральных ресурсах таких соседних с Россией стран, как Узбекистан и Таджикистан, выявляется правовой опыт регулирования недропользования в других государствах при сопоставлении с международно-

\footnotetext{
- Зикиряходжаев Лазис Дильшадович - аспирант кафедры международного права МГИМО (У) МИД России.

'Горное дело и окружающая среда: мировой опыт правовой гармонизации: Словарь / Под ред. акад. В.Ж. Аренса, А.Н. Вылегжанина. М., 2000.
} 
правовым опытом. При этом имеется в виду, что между Узбекистаном, Таджикистаном и Россией особенно целесообразно сотрудничество по управлению трансграничными минеральными ресурсами.

Законы о недрах и в Узбекистане, и в Таджикистане были приняты лишь в 1994 г., т.е. со времени распада Союза ССР и образования на базе его бывших республик независимых государств - членов $\mathrm{OOH}$ и до принятия данных законов прошло относительно немного времени. Структура названых законов весьма схожа, за небольшими исключениями. За период применения этих законов они не раз подвергались изменениям и дополнениям, в том числе относительно недавним.

Оба закона трактуют понятие недр как «часть земной коры, расположенную ниже почвенного слоя и дна водных объектов, простираюшуюся до глубин, доступных для геологического изучения и освоения» (ст. 2 закона «О недрах» Узбекистана; общие положения закона «О недрах» Таджикистана).

Это положение обоих законов по сути совпадает с соответствующим положением российского Федерального закона «О недрах»: «Недра являются частью земной коры, расположенной ниже почвенного слоя, а при его отсутствии - ниже земной поверхности и дна водоемов и водотоков, простирающихся до глубин, доступных для геологического изучения и освоения» (Преамбула Ф3 «О недрах» 1992 г., с посл. изм., в том числе внесенными Ф3 от 29 мая 2002 года). В комментарии к этому закону не обращено внимания на то, что российский законодатель самоограничил лишь одной геосферой - земной корой - подземный предел недр ${ }^{2}$. А в международно-правовой литературе показано, что такое самоограничение не диктовалось международным правом: США, которые такого самоограничения не делали, не нарушали международное право ${ }^{3}$.

Целью анализируемых законов Таджикистана и Узбекистана провозглашено регулирование отношений, которые возникают при владении, пользовании и распоряжении недрами. В первом разделе рассматриваемых законов содержатся общие положения: об обеспечении рационального, комплексного использования недр; охране недр; охране прав пользователей недр; защите интересов личности, общества и государства.

Крассов О.И. Комментарий к Закону Российской Федерации «О недрах». М., 2003. C. 13-30.

'См.: Вылегжанин А.Н. Подземный предел распространения суверенитета государств // Государство и право. 2001. № 8. 
Провозглашено, что право собственности на недра в пределах данных стран является исключительным правом государства, т.е. недра являются исключительно объектом государственной собственности. А вот право собственности на добытые полезные ископаемые уже доступно, согласно гражданскому законодательству для вешных прав лиц. Статья 6 закона Узбекистана «О недрах» предусматривает, что полезные ископаемые (добытые) могут находиться в государственной собственности, а также в собственности юридических и физических лиц. В Законе Таджикистана этот вопрос о правах на полезные ископаемые решен нечетко. Согласно этому закону частная собственность на недра не допускается, купля-продажа, дарение, залог участков недр и самовольный обмен ими запрешаются (ст. 2). Правовой режим ресурсов in situ, как и полезных ископаемых, специально не определен.

Как уже отмечалось, существуют некоторые различия в законодательном регулировании отношений недропользования в двух государствах. Согласно Закону Таджикистана «О недрах» управление государственным фондом недр в интересах всего населения страны осуществляется Правительством Республики Таджикистан. Некоторой компетенцией в этой сфере обладает и Маджлиси Олий - Верховный Совет Республики Таджикистан. Государственному регулированию отношений недропользования посвящен раздел IV данного закона. Что же касается закона «О недрах» Узбекистана, то государственное управление недрами возложено на Кабинет Министров Республики Узбекистан, органы государственной власти на местах, а также специально уполномоченные государственные органы. Такими органами являются Государственный Комитет Узбекистана по охране природы, Государственный Комитет Узбекистана по геологии и минеральным ресурсам, Агентство по надзору за безопасным ведением работ в промышленности и горному надзору (ст. 7 закона «О недрах» Узбекистана).

Ключевое место отведено в законах регламентации использования недр, причем и в этом вопросе проявляются неодинаковые подходы законодателей. На этом целесообразно остановиться.

Пользование недраии в Республике Узбекистан. Согласно ст. 20 закона «О недрах» пользователями недр могут быть юридические и физические лица. Недра могут предоставляться в срочное (временное) и бессрочное пользование. Сроки временного пользования зависят от того или иного вида деятельности в области недропользования. 
В бессрочное же пользование могут предоставляться участки недр для строительства и эксплуатации подземных сооружений, не связанных с добычей полезных ископаемых, а также образования особо охраняемых геологических объектов. Под последними, согласно ст. 2, понимаются «научные и учебные полигоны, геологические заповедники, памятники природы, пешеры и другие подземные полости, имеюшие научное, историческое, культурное, эстетическое и иное значение».

Основанием возникновения у конкретного лица права пользования участками недр для геологического изучения, добычи полезных ископаемых, использования минеральных техногенных образований и иных целей, не связанных с добычей полезных ископаемых, является лицензия. Лицензия выдается юридическому или физическому лицу органом, уполномоченным выдавать лицензии; осуществляется такая выдача по результатам публичных торгов или прямых переговоров юридических или физических лиц с соответствующим органом (ст. 27). Лицензии могут выдаваться Государственным комитетом Узбекистана по геологии и минеральным ресурсам, Государственным Комитетом Узбекистана по охране природы и другими уполномоченными Кабинетом Министров Республики Узбекистан органами. При этом многое зависит от вида недропользования. Заслуживает внимания ст. 28 Закона, которая регламентирует отношения пользователей горного отвода. В соответствии с лицензией для добычи полезных ископаемых, использования минеральных образований, строительства и эксплуатации подземных сооружений, не связанных с добычей полезных ископаемых, недра предоставляются в виде участков, ограниченных по площади и глубине (горный отвод). Хозяйственная и иная деятельность в границах горного отвода может осуществляться только с согласия пользователя недр, которому он предоставлен. Горные отводы предоставляются Агентством по надзору за безопасным ведением работ в промышленности и горному надзору, а порядок их предоставления определяется Кабинетом Министров Узбекистана.

Права и обязанности пользователей недр достаточно объемно расписаны в рассматриваемых законодательных актах. Пользователи недр имеют право:

- использовать предоставленный им участок недр для любой формы предпринимательской или иной деятельности, соответствующей цели, обозначенной в лицензии; 
- использовать результаты своей деятельности, включая полученную информацию о недрах, а также добытые полезные ископаемые или их долю;

- использовать техногенные минеральные образования, полученные в прочессе добычи полезных ископаемых и переработки минерального сырья;

- проводить без дополнительных разрешений геологическое изучение недр в границах горного отвода, предоставленного в соответствии с лицензией;

- использовать отходы своего горнодобываюшего производства, если иное не оговорено в лицензии, а также целый ряд иных прав в соответствии с законодательством.

К наиболее важным обязанностям пользователей недр можно отнести следующие:

- пользоваться участком недр в соответствии с целью, для которой он предоставлен;

- соблюдать нормы и правила по технологии ведения работ, связанных с пользованием недр и переработкой минерального сырья;

- сохранять добываемые, но временно не используемые попутные полезные ископаемые и обеспечивать их сохранность;

- предоставлять в порядке, установленном законодательством, данные об объеме добытых полезных ископаемых;

- соблюдать утвержденные в установленном порядке стандарты (нормы, правила), регламентируюшие условия охраны недр, атмосферного воздуха, земель, лесов, вод и т.п.

Пользование недрами в Таджикистане. Порядок пользования недрами, установленный во втором разделе закона «О недрах» данной республики, сушественно не отличается от изложенного выше порядка, предусмотренного законом Узбекистана «О недрах». Нормы закона Таджикистана предусматривают и практически аналогичный порядок лицензирования. Тем не менее есть незначительные различия. К примеру, ст. 10 указывает на то, что пользователями недр, наравне с юридическими и физическими лицами, могут быть и граждане других государств, если другое не предусмотрено законодательными актами Республики Таджикистан.

Заключительные части рассматриваемых законов посвящены ответственности за нарушение законодательства о недрах. Указывается, в частности, что лица, виновные в нарушении законодательства 
о недрах, несут ответственность в установленном порядке. Статья 49 закона Таджикистана «О недрах» перечисляет нарушения, которые влекут за собой ответственность. Среди них: нарушение порядка пользования недрами; самовольное пользование недрами; необеспечение сохранности особо охраняемых территорий и объектов окружающей природной среды и т.п.

Споры по вопросам пользования недрами разрешаются органами государственной власти и управления или судом в соответствии с компетенцией и в порядке, установленном законодательством (ст. 51 закона «О недрах» Узбекистана; ст. 50 закона «О недрах» Таджикистана).

Несомненно, эти основополагающие правовые акты по недропользованию были приняты своевременно, они предотвратили анархию бизнеса в республиках. В настоящее время эти законы играют очень важную роль в упорядочении деятельности в сфере недропользования. Законодательство о недрах этих республик, наряду с законами о недрах, состоит также из иных актов, постановлений и распоряжений, принимаемых органами государственного управления. Несмотря на наличие этих законов, надо констатировать, что в целом в рассматриваемых странах горное законодательство во всем его нормативном массиве пока не кодифицировано - даже в Таджикистане, значительную часть территории которого занимают горы, где имеются огромные запасы ценных пород и минералов, не имеющих аналогов в мире. Закон «О недрах» Узбекистана лишь ориентирует регулирование горных отношений в их совокупности.

В рассматриваемом законодательстве двух государств отсутствуют специальные акты (или отдельные разделы в законодательных актах), посвященные регулированию отношений, возникающих в связи с использованием трансграничных минеральных месторождений. Например, фактически Узбекистан имеет на границе с сопредельными государствами залежи нефти и газа. И отсутствие четко сформулированных правил управления трансграничными минеральными ресурсами на уровне международного договора и закона зачастую вызывает трудности и споры.

Сегодня практически перед всеми современными государствами возникает проблема определения правового положения трансграничных минеральных ресурсов, т.е. тех, которые залегают по обе стороны государственной границы между двумя соседними государствами. В международно-правовой практике уже нарабатываются некоторые 
механизмы управления трансграничными минеральными ресурсами, причем как на межгосударственном, так и на национальном уровне, при надлежащей координации. Достаточно в этом плане сослаться на международные договоры о приграничном сотрудничестве (например, соглашения России с КНР о режиме российско-китайской государственной границы 1994 г.; СССР с Монголией о режиме государственной границы 1980 г), в которых затрагиваются вопросы сотрудничества в области горного дела.

На современном этапе, в условиях экономических реформ в России, Узбекистане и Таджикистане, управленческая, коммерческая, производственная деятельность в сфере использования трансграничных минеральных ресурсов все более регулируется нормами права. Соответственно требуется уточнить применимые международно-правовые нормы, сопоставить с ними национальные законы стран, в пределах территорий которых залегают трансграничные минеральные ресурсы. И российское, и узбекское законодательство обязывает пользователей недр сотрудничать при эксплуатации трансграничных ресурсов с целью рационального использования и охраны недр, хотя налицо отличия в отсылках к конкретным механизмам и методам такого сотрудничества. В их числе - механизм организации пула недропользователей (юнитизации), который становится распространенным договорным способом взаимодействия при разработке трансграничных минеральных ресурсов.

В развитых странах функционируют довольно мощные научные центры, включаюшие и крупные подразделения, разрабатываюшие проблемы горного права. Они имеют статус государственных, частных и смешанных учреждений. Из наиболее известных можно отметить действующие в США Институт горного права в Батон-Руже при государственном университете в штате Луизиана ${ }^{4}$, Институт горного права в штате Колорадо, Институт горного права в Скалистых Горах 5 . В Канаде вопросами правового регулирования недропользования успешно занимается Канадский институт природоресурсного права в Калгари. В Германии вопросами горного права активно занимается Школа правовых исследований горного права в университете г. Мюнстер.

\footnotetext{
'Baton Rouge, Luisiana State University. Law school and General Extension Division, USA.

s Rocky Mountains Minerals Law Institute.
} 
Многие правоведы отмечают стремительный темп развития современного законодательства о недрах в последние годы. Перед развитыми странами встала проблема коренной структурной перестройки горных отношений. В горнодобывающей отрасли основными направлениями являются изменение капиталовложений, изменение производственной базы, переход к новым технологиям, развитие информационной инфраструктуры, ведение жесткого экологического регулирования и т.д. Эти радикальные изменения, естественно, находят отражение и в значительном обновлении законодательства.

Содержание горного законодательства составляют правовые акты и законодательные нормы, регулируюшие горные отношения в той или иной стране 6 . Оно определяется в каждой стране в зависимости от сложившейся правовой системы. Вместе с тем ядро горного законодательства составляет регулирование отношений недропользования. Сушественное влияние на структуру горного законодательства оказывает принятая система отношений собственности. Прежде всего следует отметить, что права собственности на месторождение или участок недр ${ }^{7}$ зависят от прав собственности на находящийся над месторождением земельный участок. В системе горного права западных стран существует деление природных ископаемых на связанные с земельным участком и не связанные с ним. Таким образом определяется основной критерий разграничения полезных ископаемых на добываемые шахтным способом и открытым способом.

Подобное деление законодательства, привязанное к шахтному или карьерному виду горного производства, традиционно сложилось во Франции, Англии, ФРГ и ряде других стран.

Как специализированная подотрасль горного законодательства сформировалось в настоящее время законодательство о нефтегазодобыче. В особую подотрасль горного законодательства выделяется также добыча радиоактивных полезных ископаемых. Регулированию отношений по использованию полезных ископаемых посвящены положения конституций некоторых развитых стран, в основном горнодобывающих. Так, земля и недра по Конституции ФРГ «могут быть в целях

${ }^{6}$ См., например: Российское горное законодательство. Документы и комментарии / Под редакцией В.Ж. Аренса, А.Н. Вылегжанина. М., 1996.

' Участок недр в законодательстве Франции, например, определяется как месторождение, ограниченное опущенными по периметру выделенного участка от поверхности Земли сужающимися к центру Земли вертикальными линиями (ст. 28 Горного кодекса Франции). 
обобшествления переведены в общественную собственность или в другие формы общественного хозяйства законом» (ст. 15). Весьма детальное регулирование горных отношений (для уровня основного закона) находит отражение в конституциях стран Латинской Америки. Среди них можно выделить конституции Аргентины, Бразилии и Мексики. Последние две являются федерациями, что представляет интерес для России с точки зрения подходов к оформлению публичных прав на недра и размежеванию компетенции в сфере государственного регулирования и управления ресурсами недр между соседними странами и субъектами федерации. Конституции этих стран закрепляют за государством в числе прочих и право собственности на недра и это

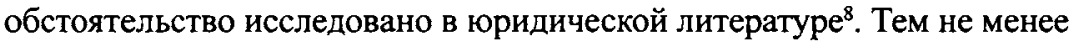
в порядке уточнения отметим следуюшее.

Одна из старейших конституций - Конституция Аргентины 1853 г. (с последними изменениями 1994 г.) прямо относит к полномочиям высшего законодательного органа страны принятие горнорудного кодекса (ст. 72 , п. 2$)^{9}$, она устанавливает первоначальное право провинций владеть природными богатствами на всей территории.

В Федеративной Республике Бразилкя Конституция детально регулирует обширный круг вопросов горных отношений. Она устанавливает, что собственностью федерации являются природные богатства, включая минеральные ресурсы. Государство активно вмешивается в развитие экономических отношений, в том числе и в области горных отношений. Оно осуществляет функции контроля, поощрения и планирования; эти функции являются обязательными для государственных предприятий и рекомендательными для частного сектора. В п. 4 и 9 ст. 20 Конституции Бразилии к собственности федерации отнесены «природные богатства» и «минеральные ресурсы, включая и те, которые находятся в недрах».

Значительное внимание уделено горным отношениям и в законодательных актах Мексиканских Соединенных Штатов. Конституция устанавливает, что непосредственной собственностью нации являются все природные ресурсы, в том числе континентального шельфа и зоны морского дна, а также обширный перечень полезных ископаемых, которые имеют другую природу (ст. 27). Принятие законов о горно-

\footnotetext{
${ }^{8}$ Клюкин Б.Д. Горные отношения в странах Западной Европы и Америки. М., 2000.

${ }^{\circ}$ Конституции зарубежных стран. Американский континент. Сборник официальных текстов. Ереван, 1998.
} 
добываюшей промышленности, добыче углеводородов относится к компетенции федерации.

Горный Закон ФРГ (от 13 августа 1980 года) и в целом германское горное законодательство предусматривают, что имущественные и обязательственные отношения в этой области в значительной мере регулируются Германским гражданским уложением. Определяя сферу и пространственные пределы действия горного законодательства, данный закон (ст. 1) установил обширный круг отношений, регулируемых этим законодательством. В их числе отношения:

- по упорядочению и содействию поиску, разработке и обогащению полезных ископаемых с учетом их связи с определенной территорией и охраны месторождений;

- по обеспечению безопасной деятельности предприятий и работников горной промышленности;

- по повторному использованию свободных для горного промысла земель во время и после поиска, разработки и обогащения полезных ископаемых.

Горный Кодекс Франции (1995 г.) охватывает обширный круг отношений. Он регулирует и правовой режим месторождений полезных ископаемых, и правовой режим горных предприятий, всю совокупность отношений по разведке и эксплуатации месторождений, порядок приобретения и прекращения прав на горные концессин, горную аренду и деятельность национализированных шахт, отношения по административному надзору за деятельностью горных предприятий, ответственность за нарушение горного законодательства.

Горное законодательство представляет собой специальное законодательство, включающее законодательство о правах на недра, находящиеся в них полезные ископаемые, включая право собственности на них государства и иных субъектов гражданских отношений (Жан Персон). Эта специфика горного законодательства определяется значимостью полезных ископаемых для национальной экономики как невозобновляемых природных ресурсов. Горное законодательство включает регулирование работ по эксптуатации недр в целях добычи полезных ископаемых, вопросов техники безопасности персонала горнодобывающей промышленности, акты и нормы по охране окружающей природной среды. Выступая как автономная область законодательства, оно тесно переплетается с гражданско-правовым, экологическим и трудовым, а в области охраны недр, кроме того, с административным и утоловным законодательством ${ }^{10}$.

\footnotetext{
${ }^{10}$ Клюкин Б.Д. Горные отношения в странах Западной Европы и Америки. М, 2000.
} 
Законодательство о недропользовании, в целом все природоресурсное право Австралии включают в себя целый ряд актов, которые регулируют отношения в сфере использования не только минеральных богатств этой страны, но и иных природных ресурсов, а также защиты окружающей среды. Это законодательство имеет большую историю; отметим, что его возникновение относится к периоду «золотой лихорадки» 1850 г. До этого периода отношения в данной сфере регулировались в различных колониях общим правом (common law) Англии. Согласно обшему праву принципиального различия между режимом минеральных ресурсов и земельным правом не было. За исключением «королевских металлов» - золота и серебра, права на остальные минералы оставались за владельцем земли наравне с правами на эту землю. История показывает, что последующее развитие природоресурсного законодательства Австралии протекало достаточно быстрыми темпами, хотя наряду с положительными моментами имело и некоторые недостатки".

В настоящее время территориальный суверенитет Австралии распространяется на все относящиеся к ней земли и их недра, недра дна внутренних вод и территориального моря.

Федеративная система Австралии служит инструментом распределения прав над недрами и минеральными ресурсами между двумя государственными уровнями: федеральным и субъектами федерации. Законодательство предусматривает разные права над недрами и их ресурсами в целом в пределах территории государства, на конкретных территориях и в прилегающих морских зонах.

За некоторыми исключениями, федеральная власть и власть субъектов федерации в отношении недропользования действуют совместно. Так что в случае вмешательства федерации субъекты могут регулировать даже те действия, которые входят в компетенцию федерации. Одновременно, если закон субъекта федерации противоречит федеральному закону, ст. 109 Конституции признает федеральную норму преобладающей. Минеральные ресурсы, нефть в пределах государственных границ в Австралии не отнесены к объектам, по режиму которых разграничение четко обозначено.

Что касается правового режима минеральных ресурсов территорий, то федеральный парламент имеет полную законодательную власть

"Об австралийском и ином иностранном горном законодательстве см., например: Правовой режим минеральных ресурсов / Под. ред. А.А. Арбатова, А.Н. Вылегжанина. М., 2002. 
по отношению к территориям (ст. 122 Конституции). Сушествуют лишь некоторые ограничения по отношению к тем территориям, которые имеют особый статус.

В период 1950-х годов, когда было начато активное использование морских минеральных ресурсов, имелись сомнения по поводу размежевания властных полномочий федерации и ее субъектов в части регулирования отношения недропользования на дне территориального моря и на континентальном шельфе. В 1962 г. были начаты переговоры между правительствами субъектов федерации, которые были направлены на решение проблемы минеральных ресурсов свободных зон. Результатом этих переговоров стало Соглашение с федерацией от 16 октября 1967 года, описываюшее межфедеральные отношения по исследованию и использованию нефтяных запасов и других минеральных ресурсов подводных земель. В последующем появились и иные нормативные акты по регулированию таких отношений: закон 1973 г. «О морях и подводных землях»; закон 1980 г. «О прибрежных водах»; закон 1981 г. «О морских минеральных ресурсах» и др.

В заключение отметим следующее. Во-первых, очевидны различия в законодательных подходах различных государств к определению режима недр. Во-вторых, международное право уже содержит важные положения, применимые к деятельности государств по пользованию недр. В-третьих, исследование правового режима недр только с позиций гражданского права неизбежно влечет к искажению реальной правовой действительности. В-четвертых, приоритетным объектом научного исследования с точки зрения международного права являются трансграничные минеральные ресурсы. Если они станут объектом лишь законодательного регулирования, не будет общеприемлемой правовой основы урегулирования конфликтов в связи с использованием этих ресурсов. 